Article

\title{
Evaluating Outwards Regeneration Effects (OREs) in Neighborhood-Based Projects: A Reversal of Perspective and the Proposal for a New Tool
}

\author{
Valeria Saiu \\ Department of Civil \& Environmental Engineering and Architecture, University of Cagliari, 09123 Cagliari, Italy; \\ v.saiu@unica.it
}

Received: 29 September 2020; Accepted: 17 November 2020; Published: 17 December 2020

\begin{abstract}
This paper proposes a reversal of perspective in the evaluation of Regeneration projects. Until now, attention has been mainly focused on project "internal effectiveness", in reference to the environment and life quality improvement of the areas directly affected by the interventions. The effects induced in the wider urban context are rarely sufficiently analyzed. This aspect instead opens an important field of investigation, useful for a broader assessment of regeneration initiatives, especially with regards to Public Housing Neighborhoods where the long-term project success also depends on the positive effects it generates in the surroundings. Therefore, the aim of this research is to develop a conceptualization of "Outwards Regeneration Effects" (OREs), based on an extensive literature review, and to make it operational through a conceptual framework for the qualitative analysis. The results of this study, on the one hand, highlight several critical issues raised by the interventions implemented so far, and, on the other hand, provide a more effective assessment framework, useful in the evaluation of future projects. Further developments of such an approach could lead to the development of operational evaluation models, combining both qualitative and quantitative indicators, starting from the implementation of the proposed analytic framework.
\end{abstract}

Keywords: urban regeneration; public housing neighborhoods; project-induced effects; assessment framework; multi-criteria decision-making model

\section{Introduction}

The regeneration of public housing neighborhoods periodically becomes a political and policy priority. This often occurs in periods of socio-economic crisis, during which specific interventions are promoted by central and local governments that allocate substantial funds in order to face an emergency condition. In this context, area-based initiatives are privileged because they respond to the need to identify priority project areas and to optimize economic resources. However, this approach, not being tied to long-lasting and overall development strategies, often does not trigger long-term transformation processes, bringing about a feeling of helplessness among administrators, economic operators, and citizens. In this way, the negative perception of deprived neighborhoods is often even further reinforced, producing a vicious circle from which it is difficult to escape.

According to these considerations supported by a literature review (Section 2), this paper suggests a reversal of perspective, shifting attention from the effects produced by interventions within the neighborhood which characterize the area-based approach, towards the effects on the surroundings, which are defined here as "Outwards Regeneration Effects" (OREs) (Section 3). To explain this concept, the proposed analysis refers to the study conducted by Peter Hall in the late 1990s, who highlighted the differences between an "inward-looking" and "outward-looking" policy approach to the regeneration of peripheral housing estates [1]. The first—typical locality-based regeneration policies—are directed 
towards solving internal problems, largely ignoring the impacts of the external environment on the estate involved in the intervention and vice versa; the second pay attention to the external factors and their relationships with the area of intervention.

Hall's study is still very topical and can fruitfully be used as a theoretical basis to develop an operative assessment model for urban regeneration programs and projects. To that end, the proposed extension of Hall's approach allows passing from the analysis of outward-looking policies to the evaluation of the project-induced effects. By trying to overcome the area-based approach, in fact, the present proposal recognizes the main factors that affect the areas surrounding the project site, and hence propose a conceptualization of the Outwards Regeneration Effects (OREs). The purpose of this study is to develop a preliminary comprehensive framework for qualitative analysis for such OREs, useful to elaborate on more detailed evaluation models at a later stage.

In Section 4, some conclusive reflections on the usefulness of this framework are presented. On the one hand, OREs analysis provides an alternative explanation of the success/failure factors in regeneration projects; on the other hand, it offers a tool for quick assessment of the future projects' effects.

\section{Literature Review}

\subsection{The Spatial Concentration of Decay and Poverty: An Effective Representation?}

Since the 1980s, many governments have promoted a wide range of policy initiatives in order to ameliorate the conditions of deprived urban areas. Among these, EU countries are the most committed to the development of regeneration intervention, thanks to the financial support of the European Community, which has allocated specific funds for this purpose [2-8]. The rapid growth of cities after the Second World War, in fact, was mainly characterized by poor building and urban quality, especially in relation to infrastructure, services, and public space. This condition concerns, in particular, the public housing stock that revealed enormous social, environmental, and economic problems $[9,10]$. Public neighborhoods mainly on the outskirts of cities, in fact, have been largely recognized as sites of multiple deprivations, emblems of social and physical degradation, urban areas with a concentration of disadvantaged populations who do not have access to the opportunities available to other inhabitants of the city. For this reason, housing and neighborhood regeneration, by which we can "face equity issues most directly" [11] (p. 77), represents an important field of experimentation for design and planning projects, as well as one of the main priorities of the European sustainable development agenda [12]. Governments and public administrations, at least in theory, concentrate many public investments in poor and degraded areas, in order to redistribute material and nonmaterial benefits (goods and services) and to rebalance resources within different areas of the city. However, this concept of urban equity holds certain paradoxical elements both from a socio-spatial and economic-political point of view.

(1) The socio-spatial paradox. Referring to Nancy Fraser [13], Dlabac et al. [14] (p. 3) point out how "the claims for egalitarian distribution are being displaced by claims for the recognition of identity groups", instead of considering people of any social status as "full partners in social interactions" [15] (p. 377). In this way, the spatial concentration of poverty and degradation in certain areas risks becoming a self-sustaining process, highlighting causes of the disadvantage. In addition to the physical characteristics of the neighborhoods (such as isolated location, poor quality housing, poor services, public spaces, and green areas [16]), "territorial stigmatization" [17-21], produced by the institutions, investors, and other citizens, may play a decisive role [22-26], which tends to reinforce the conditions of the residents of deprived neighborhoods. Thus, as Wacquant [20] (p. 1273) suggests, "in every country, a small set of urban boroughs have come to be universally renowned and reviled across class and space as redoubts of self-inflicted and self-perpetuating destitution and depravity". This locational stigmatization creates a "topography of disrepute" that favors the production of lasting spatial structures of privilege and advantage [27]. For this reason, often stigma persists even after regeneration 
interventions [28-30]. It follows that improving the neighborhood's reputation must be one of the priority objectives of the urban regeneration project (see: [31-33]).

(2) The political-economic paradox. The policies promoting a homogeneous distribution often generate the frustration of not being able to achieve this goal, not only for economic limits but also because a certain degree of distributional inequality is inevitable [34]. Referring to health services, Soja states that this depends in part on "the differential effects of relative location and distance friction on consumers and in part due to the locational decision made by individuals producing these services" [35] (p. 47). Criticizing Fainstein's theory of The Just City (2010) [11], Soja points out the need for "devising pro-active spatial strategies directed towards equal access to opportunities on a citywide scale" [14] (p. 1). This recalls Amartya Sen's capability approach, which in our context, may relate to equitable access to urban opportunities. This concept turns out to be particularly true in the context of globalization and its development logistics, where places must be considered active agents instead of inert containers [36] (p. 2), and their context is a potential activator of linkages with other places.

\subsection{The Area-Based Initiatives: An Effective Approach?}

According to the local area-based explanations of deprivation, many policies and studies claim that areas and problems are closely connected and consequently, to effectively face them-making governments more responsive, flexible, strategically focused, and integrated with their actions [37] (p. 318) - it is necessary to spatially delimit the area of intervention (e.g., [38-40]). The prevailing approach to urban regeneration, in fact, has been to clearly identify and define geographically the problematic areas in order to promote area-based initiatives (ABIs) focused on specific neighborhoods. However, the empirical evidence of the "area effects"-particularly for the most deprived communities—-has been contested and often suggested to be inconclusive (see: [21,41-46]). For instance, through an ex-post assessment of the URBAN Community Initiative (1994-2006)-one of the most intensive area-based initiatives launched in Europe to deal with the problems of citizens living in disadvantaged urban areas-Carpenter [24] points at the continuous disbursement of financial resources by successive governments into often the same deprived areas, claiming that this represents a proof of failure. In this respect, we can summarize the main problems highlighted by the area-based approach in two points: (1) the selection of areas and the definition of intervention limits, and (2) the lack of interest in structural causes of deprivation.

\subsubsection{The Selection of Areas and the Definition of Intervention Limits}

The selection of deprived areas eligible for funds allocation was considered a strategy to simplify urban problems and to optimize resources [1] (p. 882). As Carpenter [24] (p. 2146) notes, the area-based initiatives "play a useful role for governments, as they reinforce the perception that deprivation only exists in a few well-defined areas. Limited resources can be channeled into delimited neighborhoods and therefore the impact is greater-to the credit of the government".

Following this logic, often the delimitation of the areas of intervention are defined by administrative boundaries or by indicators developed specifically for measuring poverty in certain areas, as in the case of the Index of Multiple Deprivation (IDM) initially developed for England in the 1990s [47-49]. In reality, it is difficult to define a map of the city by which poverty and degradation can be easily circumscribed to well-defined areas because each poor neighborhood is different from the others in terms of socio-economic conditions, cultural integration, and civic evolution [50]. As Galster [51] (pp. 2112-2114) suggests, "planners and policy-makers hope to identify behaviorally meaningful, unambiguous boundaries to devise more efficacious neighborhood indicators and interventions, but the task often is confounded by a lack of congruence among local actors' perceptions of boundaries (...) It is precisely these perceptions of boundaries that are most critical in constructing theories or predictive models of neighborhood change".

Furthermore, often "much poverty lies outside areas that score highly on indices of multiple deprivations and not everyone in these areas is poor" [52] (p. 23). A significant number of poor 
people, in fact, are not geographically concentrated in areas that are classified as "deprived" [53,54], as in the case of low-density urban areas and rural areas [55,56]. As noted by Midgley et al. [57], the application of the same deprivation measures to different contexts can be misleading. Due to the variety of territorial contexts and observable problems, the choice of indicators and analysis domains may risk looking arbitrary [58]. Consequently, "the dividing line between those clusters that are of public concern and those of no public policy interest is not always clear" [59] (p. 15), and policies in favor of selected neighborhoods can become a form of spatial injustice [60].

\subsubsection{The Lack of Interest for Structural Causes of Deprivation}

In many neighborhood regeneration programs, there is a significant lack of recognition of the structural nature of deprived areas [61] (p. 768) and many such programs propose projects in "splendid isolation" [62]. With relatively cheap initiatives, ABIs allow governments to obtain visibility without having to face more complex issues [2]. Therefore, interventions on physical renewal-“highly visible and relatively easy for governments to engineer" [36] (p. 6) - have often been preferred. However, as Marcuse [63] claims, spatial remedies are necessary but not sufficient to address spatial injustices. It follows that ABIs risk becoming a kind of "curative form of urbanism" [64] (p. 619) that "reaffirms the pathological nature of neighborhood deprivation, whereby their internal characteristics are seen as the cause of the problem rather than as a symptom of wider structural factors" [65] (p. 335). In the absence of broader economic progress and deeper social reforms, physical improvements often prove ineffective over time. Problems, in fact, "may be apparent within, but are not of, areas" [44] (p. 528). In this respect, neighborhood deprivation must be assumed as a complex phenomenon, whose causes of the problems and the potential solutions often lie outside its local perimeter. As a result, the problems cannot be solved at the neighborhood level $[66,67]$, "the geographical scale across which an attribute varies often is wildly dissimilar among attributes" [51] (p. 2113). For this reason, in a multi-level spatial view of neighborhoods [68], programs and methods for distributing funds should consider the different scales at which problems arise and have some degree of flexibility to be able to make the best possible use of available information to guide decisions. For example, if the improvement of livability can be easily addressed on a neighborhood scale, especially through the improvement of the public spaces, other interventions aimed at economic development need a larger area approach. For instance, applying this reasoning to the employment policies, we can easily observe that "there would be no rationale for trying to increase the number of jobs available in a small area if it was already surrounded by areas where job availability was very high" [69] (pp. 69-70).

Observing many government initiatives in Europe and the United States, Todes and Turok [36] (p. 6) highlight the lack of concrete commitment to rebuild local economies and to create new jobs: "at worst they merely ameliorated poor living conditions, instead of being catalysts for socio-economic development". For this, it proves necessary to consider the uneven economic gains of distribution processes that limit the access to the labor market or credit services for inhabitants of degraded areas [70] and favor the concentration of wealth away from disadvantaged people and places [24] (p. 2146). Furthermore, "problems of duplication and overlap may arise in relation to policy issues and the targeting of clients and/or areas" [71] (p. 96) which may simply displace problems between different neighborhoods without addressing the overall economic and social well-being of the city as a whole [39]. ABIs, in fact, are only part of any solution [50] and they cannot solve the "global" problem [72].

\section{A Conceptual Framework for Outward Regeneration Effects (OREs) Analysis}

From the previous considerations, it appears that if many questions remain unresolved, it is in part due to the inability to represent the deprived neighborhoods as the outcome of an articulated and heterogeneous set of complex interconnected and multi-scalar processes and, therefore, to understand the extent of the effects that each intervention can produce in the wider urban context, and vice versa. 


\subsection{From Inward to Outward-Looking Approaches to Housing Regeneration}

An interesting conceptualization of the critical issues described previously is provided by Peter Hall [1] who, while analyzing the regeneration policies applied since the mid-1980s in England and Scotland, highlighted the prevalence of an "inward-looking" approach, aimed at identifying and solving internal problems (spatial and social characteristics of the neighborhood itself). In contrast, external problems (economic, social, and political characteristics of the wider city environment), referred to as an "outward-looking" approach, are not adequately taken into account. The differences between these two approaches are highlighted in Table 1.

Table 1. Inward and outward-looking regeneration policies (source: [1]).

\begin{tabular}{|c|c|c|}
\hline \multirow{2}{*}{ Policy Aspect } & \multicolumn{2}{|c|}{ Policy Focus } \\
\hline & Inward-Looking & Outward-Looking \\
\hline Environment, Access, and Amenity & $\begin{array}{l}\text { improve environment and } \\
\text { provision of amenities for locals }\end{array}$ & $\begin{array}{l}\text { - } \quad \text { overcome physical isolation } \\
\text { - } \quad \text { transport planning } \\
\text { - } \quad \text { improved amenity to } \\
\text { attract outsiders }\end{array}$ \\
\hline Housing & $\begin{array}{l}\text { improve housing conditions and } \\
\text { diversify tenure for locals } \\
\text { decentralized management }\end{array}$ & $\begin{array}{l}\text { improve housing to attract } \\
\text { new residents } \\
\text { - } \quad \text { attention to city-wide } \\
\text { housing allocation processes }\end{array}$ \\
\hline Social Regeneration & $\begin{array}{ll}\text { - } & \text { community/tenant involvement } \\
\text { - } & \text { crime strategies } \\
\text { - } & \text { stabilization of existing population }\end{array}$ & $\begin{array}{l}\text { - } \quad \text { measures aimed at } \\
\text { overcoming stigmatization } \\
\text { and social exclusion }\end{array}$ \\
\hline Economic Regeneration & $\begin{array}{l}\text { - local employment in estate } \\
\text { management and construction } \\
\text { small business development } \\
\text { and training }\end{array}$ & $\begin{array}{ll}\text { - } & \text { education } \\
\text { - } & \text { recruitment and placement } \\
\text { - } & \text { linking estate to } \\
& \text { sub-regional development } \\
\text { - } & \text { attracting inward investment }\end{array}$ \\
\hline Institutional Arrangements & $\begin{array}{l}\text { emphasis on tenant and housing } \\
\text { associations control: } \\
\text { area-based partnerships }\end{array}$ & $\begin{array}{l}\text { - emphasis on } \\
\text { city-wide partnerships } \\
\text { emphasis on linkages } \\
\text { between institutions }\end{array}$ \\
\hline Spatial Scale & $\begin{array}{l}\text { - } \\
\text { - } \\
\text { strongly decentralized } \\
\text { planning approach }\end{array}$ & $\begin{array}{l}\text { - linkage of areas of } \\
\text { deprivation and potential } \\
\text { - } \quad \text { city-wide strategic planning }\end{array}$ \\
\hline
\end{tabular}

However, despite Hall's holistic view of urban problems and policies, his examination of the outward-looking approach is mainly aimed at evaluating the "inward effects" to the project area. What the urban context gains or loses from the project is not the focus. The extension of Hall's analysis in this direction can provide useful elements for understanding the set of direct and indirect effects on the surroundings that any intervention can generate. Each renewal project, in fact, may permeate outside the area where it is implemented [73] and produce positive or negative post-development "externalities" on its neighborhoods, which must be carefully evaluated. As noted by Melo and Cruz [74] (pp. 1-4), "the effects of urban renewal are wider than the physical assets under intervention and have social, economic, and environmental implications to agents (owners, tenants, local businesses, etc.) that are not involved in the renewal processes.... Quantifying externalities should be considered as the starting point to the improvement of those relations between neighborhoods, contributing to an overall improvement of the city". 
For all this, a comprehensive evaluation of inward and outward regeneration effects allows for the understanding of the impacts of projects/programs and can constitute one of the strongest arguments available from public administration for justifying any renewal intervention. This can seek to unseat, not only conceptually but also operationally, an inward based approach, which, as previously described, is still prevalent. Above all, it answers a fundamental question: "who are the neighborhood-based policies designed for, and who will these policies disadvantage either intentionally or unintentionally? " [75]. According to Miceli et al. [76], quantifying externalities is the starting point to the improvement of those relations between neighborhoods, improving the city to which they belong. To this end, the next paragraph introduces the concept of "Outward Regeneration Effects" (OREs), identifying some main categories of analysis. Figure 1 schematizes, through a system of concentric circles, the neighborhood where regeneration actions are foreseen, its surroundings, and the wider urban context where the outwards effects are expressed.

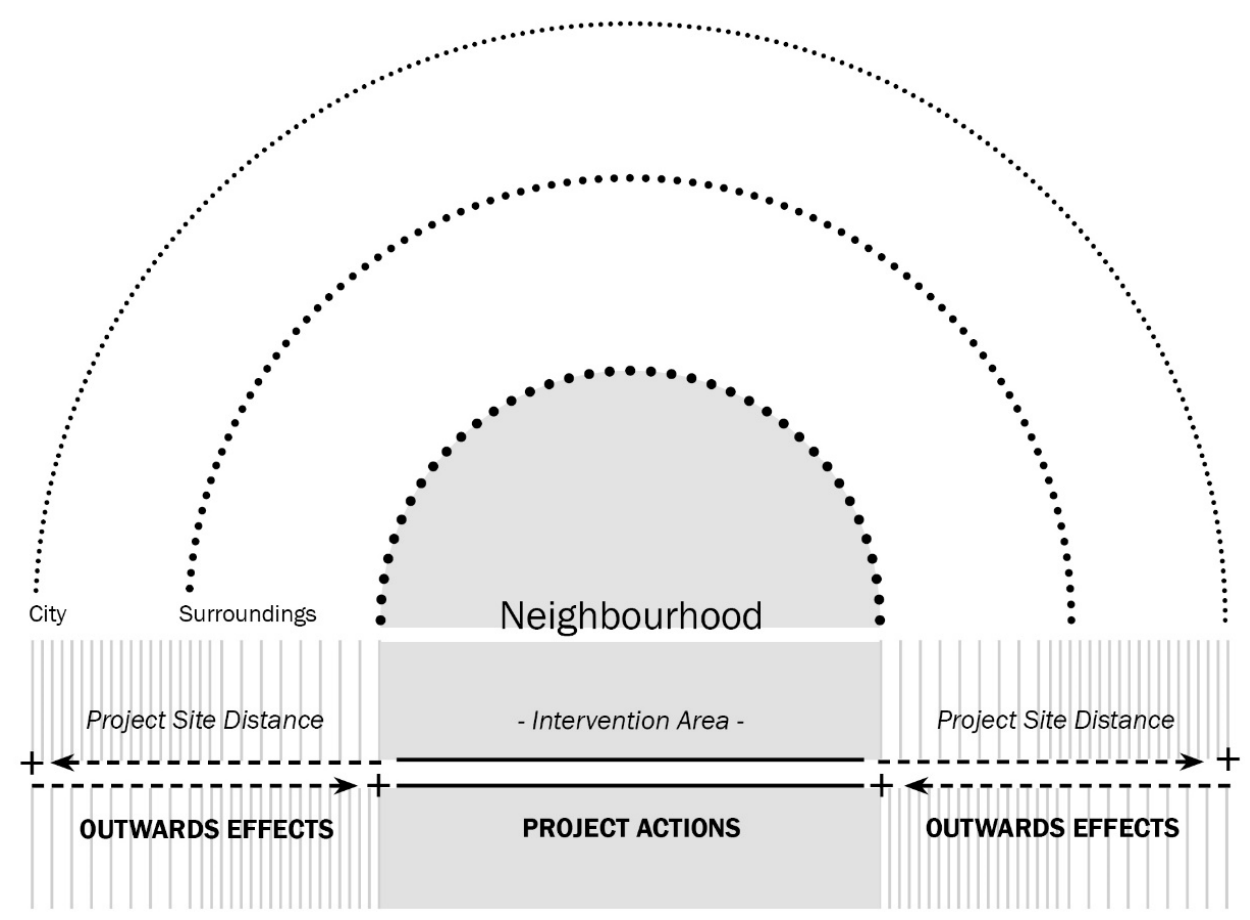

Figure 1. Outward Regeneration Effects (OREs): explanatory scheme. In the center, the renewed neighborhood (intervention area) and the subsequent levels corresponding to the urban context in which the effects of intervention occur, the surrounding neighborhoods and the whole city context, respectively.

\subsection{OREs: Definitions and Qualitative Evaluation}

In order to move from theory to practice-with reference to the extensive literature review mainly based on case study analyses discussed in the two next sub-paragraphs (Sections 3.2.1 and 3.2.2)—the outward-looking policy focus identified by Hall has been associated with a series of Outwards Regeneration Effects (Figure 1, Table 2). These were put in the form of questions, as a preliminary questionnaire to be submitted to local administrators and planners. Each of these-described in the literature in terms of impacts, externalities, spillover effects, etc.-have typically been analyzed independently of one another, in reference to a specific sector of analysis (economic, social, transportation, etc.). The usual approach, in fact, is to take some aspect of data to capture and represent a given phenomenon. Nevertheless, if we only focus on a single effect, we risk underestimating the overall effect's size. Therefore, this study proposes a comprehensive conceptual framework for the qualitative analysis of project actions and their induced effects. 
Table 2. The outward-looking approach and its corresponding Outwards Regeneration Effects.

\begin{tabular}{l}
\hline \multicolumn{1}{c}{ Outward-L } \\
\hline Objectives * \\
\hline - Accessibility and Attractivity \\
- $\quad$ Create new spatial and functional \\
- $\quad$ Ovelationships with neighboring areas \\
- Attract outsiders
\end{tabular}

- Attract outsiders
- Improve public transport and soft mobility

- Enhance amenities and commerce Outwards Regeneration Effects ** Preliminary Questions

- What spatial and functional relationships are defined between neighboring neighborhoods?

- Do new transport networks ameliorate the connectivity of surrounding neighborhoods?

- Do new amenities and commerce expand the offer already present in the surrounding urban area?

\section{Housing Implementation}

- Attract new residents

- Diversify the housing offer
- Recovery and enhancement of existing housing stock

- Develop new housing, especially urban infill
- Does housing improvement cause a rise in prices of surrounding residential markets?

- Does the new housing offer expand the residential choice by providing alternatives in the neighboring housing market?

\section{Social Regeneration}

- Overcome stigmatization and social exclusion

- Enhance human and social capital
- Improve public spaces and green areas, goods, and social welfare services

- Expand the educational and cultural offerings

- $\quad$ Are the new public spaces and green areas, goods, and social welfare services attractive to neighboring communities, and are the interactions between inhabitants of different neighborhoods encouraged?

- Are the new educational and cultural offerings also addressed to the inhabitants of the nearby neighborhoods?

- Do employment policies provide an attractive complementary offering or do they simply displace employed people residing elsewhere?

- $\quad$ Create new jobs
- Identify the economic role of the neighborhood in the wider city systems

4. Economic Regeneration

- Expand the recruitment and placement

- Link real estate to sub-regional development

- Attract outward investment.

- Attract external economic resources for the intervention implementation in order to compensate for inward and public financial cuts

- Do the new economic activities build a differentiated offering compared to the activities already present in the surrounding area?

- Do the investments have an economic return on neighboring neighborhoods?

- $\quad$ Create new city-wide partnerships

5. Inter-Institutional Cooperation Arrangements

- Foster the city-wide partnerships

- Facilitate the cross-scale institutional linkages
- Build cross-scale institutional linkages at horizontal (across space - different neighborhoods) and vertical levels (across levels-different levels of government)
- Do the new partnerships encourage cooperation between the private and public sectors and different institutions, favoring the renewal of the management models of nearby neighborhoods?

\section{Policy and Planning Integration}

- Adopt city-wide strategic planning

- Promote functional linkages between different neighborhoods.
- Include the project in broad-scale strategies for urban development

- $\quad$ Establish functional linkages between plans and projects, especially regarding neighboring neighborhoods
- Is the project part of a larger development plan?

- Do the interventions foster the development of regeneration strategies for surrounding areas?

Source: * Adapted from Hall, 1997; ${ }^{* *}$ Elaborated by the author.

Answering these questions allows for the identification of the objectives foreseen by the project/program and the related impacts on the surroundings that positively or negatively influence the outcome of the project. In this regard, the analysis pointed out that OREs are not uniform but 
depend both on the Locational and Project/Program characteristics, the combination of which produces uneven effects. The potential effects produced by these two factors are explained in the text below.

\subsubsection{Locational Characteristics (L)}

As an adage on real estate would have it, the three most important features in determining the price of a property are "location, location, location". Desirable locational characteristics - such as the accessibility to public transportation, services, stores, workplaces; the environmental values (e.g., air quality, water quality, land uses); and the quality of surrounding neighborhoods-are key factors in residential property values of the vicinity. In the same way, the proximity of deprived areas and neighborhoods depresses neighboring property values because it produces a decrease in demand and, consequently, in the market and rent prices [77-80]. The same negative impacts were also observed in the proximity of public housing developments by different authors see: [74,75]. On this, much research conducted through spatial statistics and spatial econometrics (e.g., price indices for zones and price gradient analyses) show that the distance is a significant parameter in the evaluation of locational externalities $[74,81,82]$. From this perspective, OREs are greater near the project area and decrease as we move away from it.

Moreover, each project can generate very different impacts from place to place, in relation to its features and degree of "reactivity" in an urban context; "every redevelopment project is unique in terms of its design and interaction with the neighboring environment" [78] (p. 170). Support for this thesis is shown by several studies reporting that neighborhood renewal can generate opposite effects in terms of raising surrounding property values [83-85], and, therefore, distance could be more or less a positive factor.

It follows that the impact of an investment cannot be measured without understanding its effects on the value of the neighboring land [82]. For example, as noted by Baumont [73], urban renewal promoted by public housing interventions may have direct positive impacts on surrounding properties. De Sousa et al. [83] have estimated the impacts of publicly assisted brownfield redevelopment, showing that the increase in nearby residential property values "is significant in both quantity and geographic scope, as redevelopment led to a net increase" of housing prices in nearby surroundings. Collins and Shester [86] show that the recovery and enhancement of the existing housing stock increase income and property value of surrounding areas.

From an opposite scenario, Newell [87] suggests that the overall increase in new housing supply produced by neighborhood renewal may cause economic losses on the values of homes near the development, especially if there is no growing demand for housing. In cases where the project aims to strengthen the housing supply for the lower middle class, "public housing projects allegedly increase congestion and noise, attract a majority of low-income families, thereby reinforcing the ill repute of the districts, and drive down housing values" [73] (p. 302). The attraction of further disadvantaged populations not only is likely to increase the stigma and the social exclusion of the residents but can also have negative effects on the prices of the neighboring areas. As noted by Gibbons [88], in fact, home-owners are willing to pay a substantial premium for good neighbors. By contrast, projects based on recovery and enhancement of housing stock risk to increase the rents to a disadvantage of the lower-income inhabitants, favoring gentrification processes [89-91].

Finally, another aspect that must be taken into consideration is the characteristics of the urban environment. Indeed, some studies show that impacts vary according to the classification of neighboring housing markets and the years of construction [92]. Reviewing a panel of high-rise developments in the city of Hong Kong, Chau and Wong [93] have demonstrated that urban renewal reduces the value of buildings located beyond the boundaries of the project, with greater effects for older buildings. As noted by Newell [87], new construction or renovation increases the aesthetic value of a structure and the nearby undeveloped homes are not perceived as desirable. As a result, both consumers and appraisers lower their value assessments of older homes. 


\subsubsection{Project/Program Characteristics (P)}

From previous considerations, it follows that distance, understood as geographical proximity, cannot be the only parameter that may influence positive or negative externalities. Housing externalities, in fact, depend on spatial and functional linkages that are established between the housing project and the neighborhood environment. These interactions vary for every renewal intervention that can or cannot generate a positive spillover "through a responsive and beneficial integration of the new development with the existing neighborhood" [78] (p. 156). Therefore, the evaluation of the spatial and functional characteristics of the context represents a key factor for maximizing positive synergies and attaining an efficient distribution of economic and social activities in an urban environment. Because "larger sites can also accommodate more common facilities and allow more flexible design, uses, or configurations, the lack of positive synergies arising from the economies of scale that could have been generated with the surrounding areas weakens the development potential. If they are present, the marginal gains in nearby property values will increase with the size of the residential investment" [84] (p. 27).

Furthermore, the regeneration of a well-defined area would reduce the redevelopment option value of the surrounding areas because after an area-based renewal project has been approved, the chances of new interventions being carried out in the same area decrease and, consequently, so do the investments in the surroundings of the project area. The buildings outside the regeneration area, even in the event of a subsequent intervention, would not reach the maximum regeneration potential that could have resulted from synergistic development opportunities [93]. Therefore, the neighboring neighborhoods lose the opportunity to enjoy the synergies generated by the combination of different economies of scale, with the consequent decrease of their development potential.

In this respect, it is important to consider that the progress of a renewal project can determine people's expectations for reconstruction and the possibility of replacement by new housing, as well as for the surroundings, with economic impacts on the residential market. The large-scale construction of new neighborhoods or the rehabilitation projects, in fact, "can change the relative attractiveness of existing neighborhoods" [51] (p. 2115). The concept of the neighborhood as "externality space", proposed by Galster [94], allows for the clarification of an important aspect related to the Outwards Regeneration Effects. From the individual perspective of residents or owners of property, the externality space refers to the space in which changes to the environment result from the actions of others that are perceived to be elements capable of significantly altering the level of individual well-being (psychological and/or financial). This may cause behavioral responses (e.g., migration, sale of housing, etc.) which, in turn, cause new changes to neighborhoods over the long term [51]. In this regard, Davis and Whinston [95] use a Prisoner's Dilemma analysis to explain the behavior of small owners, which tend to overlook possible improvements of existing structures, waiting for easy profits induced by the project.

Despite their importance, these aspects are still scarcely investigated or duly taken into account when projects are implemented by local governments. To deal with such issues, there is a need to take an integrated approach, so as to put to system the current and potential resources of each neighborhood, with wider regeneration strategies in the city as a whole. This view, primarily turned towards the external built environment, allows for the improvement of the perception of urban capabilities at stake, promoting the concept of opportunity as a result of positive exchange between different urban areas. In this context, social and functional mixity is not an internal condition, but the result of a resource-sharing program, according to the idea of neighborhoods as collaborative platforms [52]. As Galster [96] (p. 19) notes, in fact, "for formulating and justifying a mixed housing policy on either efficiency or equity grounds, it is crucial to understand exactly what sort of neighborhood effect(s) is operating in neighborhoods". For example, the provision of new public spaces and services can create extra local value if they are designed "outwards", not only for the inhabitants of the project area but also for a wider range of people living in the city.

The analysis of the literature highlights the existence of multiple effects, sometimes diametrically opposite, that a regeneration intervention can cause on its urban context. Table 3 shows an example of 
some of the OREs referring to the two main policy aspects-Housing and Spatial Scale-described in the text above.

Table 3. OREs: literature-based evidence of opposite effects, in reference to two of the six main policy aspects highlighted in Table 2: Housing Implementation and Policy and Planning Integration. Data reported in this table point out the positive and negative regeneration effects, in order to make the two-fold perspective more explicit and to underline the need for a thorough assessment of projects.

\begin{tabular}{|c|c|c|}
\hline \multirow{2}{*}{ Policy Aspect } & \multicolumn{2}{|c|}{ Outwards Regeneration Effects } \\
\hline & Positive & Negative \\
\hline \multirow{4}{*}{ 2. Housing Implementation } & Housing price rise & Home values depreciation \\
\hline & $\begin{array}{l}\text { The income and property value of } \\
\text { neighboring properties can rise } \\
\text { (Collins \& Shester, 2010; Baumont, } \\
\text { 2009; Bourassa, Hoesli \& Sun, 2004; } \\
\text { Hwang \& Kim, 2016; Kim et al., 2016) }\end{array}$ & $\begin{array}{l}\text { - Overall increase in new housing } \\
\text { supply and consequent depreciation of } \\
\text { home values near development, } \\
\text { especially if there is no growing } \\
\text { demand for housing (Newell, 2010) } \\
\text { - Property value reduction of buildings } \\
\text { located beyond the boundaries of the } \\
\text { project, especially older buildings } \\
\text { (Chau \& Wong, 2014) }\end{array}$ \\
\hline & Reputation amelioration & Gentrification process \\
\hline & $\begin{array}{l}\text { - New dwellings of higher quality can } \\
\text { raise the standing of the neighborhood } \\
\text { and attract higher-income residents } \\
\text { (Cumming \& DiPasquale, 1999) } \\
\text { - The arrival of new residents could } \\
\text { curtail existing bad neighborhood } \\
\text { effects by introducing "social mixity" } \\
\text { and dissuade higher-income } \\
\text { populations from moving out } \\
\text { (Baumont, 2009) }\end{array}$ & $\begin{array}{l}\text { - Increase in rents and taxes to damage } \\
\text { the inhabitants of lower incomes and } \\
\text { cause gentrification processes (Vigdor, } \\
\text { 2010; Malpezzi, 1996) that risk } \\
\text { triggering a chain effect in the } \\
\text { surrounding areas, with an increase in } \\
\text { rents and prices of houses in the } \\
\text { adjacent neighborhoods (Atkinson, } \\
\text { 2002; Shaw, 2000) }\end{array}$ \\
\hline & Raise expectations for future development & Reduction regeneration option value \\
\hline 6. Policy and Planning Integration & $\begin{array}{l}\text { - The nearby housing prices can increase } \\
\text { due to the increase in expectations for } \\
\text { a possible regeneration in neighboring } \\
\text { areas (Choi, 2019; Han \& Lee, 2009) } \\
\text { - Older apartments are rated positively } \\
\text { by the real estate market for their } \\
\text { reconstruction potential (Lee, 2004; } \\
\text { Choi, 2007) }\end{array}$ & $\begin{array}{l}\text { - Reduction of regeneration option value } \\
\text { and the consequent lack of investment } \\
\text { in the surrounding areas to project } \\
\text { (Chau \& Wong, 2014) }\end{array}$ \\
\hline
\end{tabular}

\section{Conclusions and Further Developments}

The findings of this research reveal a significant correlation between regeneration projects and the transformation of urban surroundings contextualize and highlight multiple factors that should be considered to optimize the management of decision-making processes and design choices. As highlighted by the literature review, current evaluation models are unable to consider these aspects, or they do so partially.

Trying to overcome these limits, the research shows that there is a low perception of the impacts of urban regeneration projects in their urban contexts, outside the perimeter of the project areas. In general, especially in the case of public housing neighborhoods, the project evaluation focuses on internal quality assessment of renewed areas. In this context, the analysis highlights two key issues, briefly summarized below.

(1) The effectiveness of the spatial representation of degradation and urban poverty (Section 2.1). The question we ask ourselves is whether a spatial representation of decay, which tries to limit urban deprivation processes within well-defined limits, can effectively represent the problems of a neighborhood, and therefore, suggest effective solutions. In particular, it highlights how public housing estates are subjected to targeted interventions that often neglect, or do not effectively address, structural causes of decay and poverty. This shows up in two paradoxes: (1) the socio-spatial paradox in which the delimitation of the problem areas leads to the construction of a dangerous "urban 
topography of disrepute", reinforcing the locational discrimination of the neighborhood's inhabitants; (2) the political-economic paradox, which takes place in the ideal attempt to homogeneously distribute amenities and services between different neighborhoods of the city. The impossibility of having necessary economic resources for this purpose, and above all, the different economic, socio-cultural, and spatial characteristics that distinguish the various urban areas, make this objective unattainable.

(2) The efficacy of the Area-Based Initiatives (Section 2.2). Taking into account the issues so far described, this study proposes a critical analysis of the area-based initiatives, offering a sort of an "operational translation" of the spatially circumscribed concept of urban problems. The promotion of interventions aimed at specific problem areas, in fact, shows two main underlying issues that limit the effectiveness of actions launched at the local level. First, the selection of areas and the definition of intervention limits often prove to be uncertain because it is likely to be inconsistent with the effective distribution of poverty. In this way, there is a risk of excluding from funding several deprived areas, producing new spatial injustices. Second, the search for localized solutions, mainly aimed at remedying the internal problems of neighborhoods-in the absence of interventions aimed at identifying and correcting the structural causes of degradation—contributes to the spread of curative urbanism with short-lasting effects.

The analysis of these two issues, which are the basis of the research problem, suggests the importance of shifting attention from the effects produced within the project area to the external effects induced by regeneration interventions (OREs) (Section 3). In particular, the evaluation of these requires answering two questions:

(1) What are the surroundings' gains or losses from a nearby urban regeneration project?

(2) How much does the context influence the outcome of the project?

In order to operationalize this analysis approach, the six policy aspects identified as being of relevance for decision support by Peter Hall have been declined in a number of key actions, consistent with the outward-looking regeneration approach suggested by the author. Among these are the following:

- Improving sustainable mobility (public transport networks and cycle-pedestrian paths), networking services, and commerce activities in order to promote daily population movements across different neighborhoods. This means rationalizing resources, avoiding duplicating the existing offerings, and making sure that each neighborhood can provide specific services that are useful to the entire community.

- Expanding the housing offerings (rehabilitation of the existing housing stock and new housing development, especially infill construction) in order to create diversified offerings and to attract new residents, as well as to combat the gentrification phenomena. For this to happen, it is necessary to create a new housing offering according to the wider real estate market with the objective of ensuring a broader urban social mix.

- Increasing the supply of public spaces and services - especially green areas, goods, and social welfare services, as well as educational and cultural activities and jobs-in order to expand the diversity of available options and to encourage interaction among inhabitants of different neighborhoods.

- From the point of view of institutional arrangements and planning, urban regeneration projects should be delivered through broader partnership-based governance arrangements that place more emphasis on concerted action between different neighborhoods and institutions, in order to favor the renewal of the nearby urban areas and to define city-wide regeneration strategies.

Subsequently, these actions have been turned into a set of preliminary questions that allow the qualitative evaluation of corresponding OREs, in order to outline a comprehensive conceptual framework of analysis for regeneration projects and their induced effects. This framework is defined through a significant sample of research based on the case study methodology. This research evidence was used to substantiate the OREs selection. 
The OREs analysis provides an alternative approach for assessing the success/failure factors in regeneration projects and allows a preliminary qualitative framework for the assessment of future projects. In both cases, this may have important implications in terms of urban policy because this can provide a forecast of the transformative impacts that a selected project can trigger in a wider urban context, in terms of environmental, economic, and social benefits/losses.

For this, planners and administrators should be concerned with OREs, especially in order to assess which interventions can guarantee the greatest benefits for the community. The aim of OREs analysis, in fact, is to construct a method for evaluating regeneration interventions according to equity and sustainability principles, in order to reduce one of the possible causes of the theory-practice gap [97].

The proposed research lays the ground for further theoretical exploration and empirical investigation of the subject. Further development of this research could lead to the definition of a comprehensive list of strategic and operational criteria. To that end, it will be necessary to define different qualitative and quantitative indicators, specifying the core assessment criteria for each question defined in the preliminary qualitative framework, and to select a number of relevant case studies in order to verify the effectiveness of the proposed indicators.

While this can seem straightforward at first, the implementation of the research findings into project practice requires great effort. One of the major problems, for example, is how to identify the data available in each city in order to build simple and generalizable methods for assessing OREs in different urban contexts.

This brings us to the most telling point. In order to have a great impact, the OREs evaluation will need to be introduced in ordinary planning practices. The question, therefore, becomes that of stimulating interest in this new perspective on the evaluation of regeneration projects, while improving the knowledge of project-induced impacts by the various factors involved in decision-making processes, in development planning, and in project design and implementation.

Funding: This research was supported, and the APC were provided for, by the research project "Urban capabilities and the right to the city", funded by the Department of Civil \& Environmental Engineering and Architecture, University of Cagliari.

Conflicts of Interest: The author declares no conflict of interest.

\section{References}

1. Hall, P. Regeneration Policies for Peripheral Housing Estates: Inward- and Outward-looking Approaches. Urban Stud. 1997, 34, 873-890. [CrossRef]

2. Atkinson, R. Combating Social Exclusion in Europe: The New Urban Policy Challenge. Urban Stud. 2000, 37, 1037-1055. [CrossRef]

3. Atkinson, R. EU Urban Policy, European Urban Policies and the Neighbourhood: An Overview of Concepts, Programmes and Strategies. In Proceedings of the Vital City: EURA Conference, Glasgow, Scotland, 12-14 September 2007; p. 24.

4. Scanlon, K.; Whitehead, C.; Arrigoitia, M.F. Social Housing in Europe; John Wiley \& Sons: Oxford, UK, 2014.

5. Scanlon, K.; Fernandez Arrigoitia, M.; Whitehead, C. Social Housing in Europe Oxford. Eur. Policy Anal. 2015, 17, 1-12.

6. Scanlon, K.; Whitehead, C.M.E. (Eds.) Social Housing in Europe II: A Review of Policies and Outcomes; LSE London, London School of Economics and Political Science: London, UK, 2008; ISBN 978-0-85328-313-3.

7. Whitehead, C.M.E.; Scanlon, K. (Eds.) Social Housing in Europe; London School of Economics and Political Science: London, UK, 2007; ISBN 978-0-85328-100-9.

8. Tedesco, C. The (new) places of urban regeneration. Plurimondi 2018, IV, 207-2018.

9. European Economic and Social Committee. The State of Housing in the EU 2019; European Economic and Social Committee: Brussels, Belgium, 2019.

10. Hess, D.B.; Tammaru, T.; van Ham, M. (Eds.) Housing Estates in Europe: Poverty, Ethnic Segregation and Policy Challenges; The Urban Book Series; Springer International Publishing: Cham, Switzerland, 2018; ISBN 978-3-319-92812-8. 
11. Fainstein, S.S. The Just City; Cornell University Press: New York, NY, USA, 2010.

12. Grazieschi, G.; Asdrubali, F.; Guattari, C. Neighbourhood sustainability: State of the art, critical review and space-temporal analysis. Sustain. Cities Soc. 2020, 63, 102477. [CrossRef]

13. Fraser, N. Rethinking Recognition. New Left Rev. 2000, 3, 107-120.

14. Dlabac, O.; Zwicky, R.; Hoole, C.; Chu, E.; Lee, P. Spatializing 'Just City Planning': An evaluation of citywide planning policies in relation to ghettoization and gentrification. In Proceedings of the City Futures IV Conference (EURA/UAA), Dublin, Ireland, 20-22 June 2019.

15. Dahl, H.M.; Stoltz, P.; Willig, R. Recognition, Redistribution and Representation in Capitalist Global Society: An Interview with Nancy Fraser. Acta Sociol. 2004, 47, 374-382. [CrossRef]

16. Buck, N. Identifying Neighbourhood Effects on Social Exclusion. Urban Stud. 2001, 38, 2251-2275. [CrossRef]

17. Garbin, D.; Millington, G. Territorial Stigma and the Politics of Resistance in a Parisian Banlieue: La Courneuve and Beyond. Urban Stud. 2012, 49, 2067-2083. [CrossRef]

18. Jensen, S.Q.; Christensen, A.-D. Territorial stigmatization and local belonging: A study of the Danish neighbourhood Aalborg East. City 2012, 16, 74-92. [CrossRef]

19. Wacquant, L. Territorial Stigmatization in the Age of Advanced Marginality. Thesis Elev. 2007, 91, 66-77. [CrossRef]

20. Wacquant, L.; Slater, T.; Pereira, V.B. Territorial Stigmatization in Action. Environ. Plan. Econ. Space 2014, 46, 1270-1280. [CrossRef]

21. Sisson, A. Territory and territorial stigmatisation: On the production, consequences and contestation of spatial disrepute. Prog. Hum. Geogr. 2020, 0309132520936760. [CrossRef]

22. Alves, S. The Patterns of Unemployment and the Geography of Social Housing. Int. J. Soc. Behav. Educ. Econ. Bus. Ind. Eng. 2012, 6, 2898-2906.

23. Alves, S. Assessing the impact of area-based initiatives in deprived neighborhoods: The example of S. João de Deus in Porto, Portugal. J. Urban Aff. 2017, 39, 381-399. [CrossRef]

24. Carpenter, J. Addressing Europe's Urban Challenges: Lessons from the EU URBAN Community Initiative. Urban Stud. 2006, 43, 2145-2162. [CrossRef]

25. Gough, J.; Eisenschitz, A.; McCulloch, A. Spaces of Social Exclusion; Routledge: London, UK, 2006.

26. Power, S.; Rees, G.; Taylor, C. New Labour and educational disadvantage: The limits of area-based initiatives. Lond. Rev. Educ. 2005, 3, 101-116. [CrossRef]

27. Soja, E. The City and Spatial Justice; RELOCAL: Stockholm, Sweden, 2009.

28. Hastings, A. Stigma and social housing estates: Beyond pathological explanations. J. Hous. Built Environ. 2004, 19, 233-254. [CrossRef]

29. Hastings, A.; Dean, J. Challenging images: Tackling stigma through estate regeneration. Policy Polit. 2003, 31, 171-184. [CrossRef]

30. Arthurson, K. Social Mix and the City. Challenging the Mixed Communities Consensus in Housing and Urban Planning Policies; CSIRO Publishing: Collingwood, Australia, 2014.

31. Permentier, M.; van Ham, M.; Bolt, G. Neighbourhood Reputation and the Intention to Leave the Neighbourhood. Environ. Plan. Econ. Space 2009, 41, 2162-2180. [CrossRef]

32. Permentier, M.; van Ham, M.; Bolt, G. Behavioural responses to neighbourhood reputations. J. Hous. Built Environ. 2007, 22, 199-213. [CrossRef]

33. Mouratidis, K. Neighborhood characteristics, neighborhood satisfaction, and well-being: The links with neighborhood deprivation. Land Use Policy 2020, 99, 104886. [CrossRef]

34. Hamnett, C. Urban inequality. In Handbook of Urban Geography, Cheltenham and Northampton; Schwanen, T., van Kempen, R., Eds.; Edward Elgar Publishing: Cheltenham, UK, 2019; pp. 242-254.

35. Soja, E.W. Seeking Spatial Justice; University of Minnesota Press: Minneapolis, MN, USA, 2010; ISBN 978-1-4529-1528-9.

36. Todes, A.; Turok, I. Spatial inequalities and policies in South Africa: Place-based or people-centred? Prog. Plan. 2018, 123, 1-31. [CrossRef]

37. Cameron, J.; Odendaal, N.; Todes, A. Integrated area development projects: Working towards innovation and sustainability. Urban Forum 2004, 15, 311-339. [CrossRef]

38. Harfst, J. A Practitioner's Guide to Area-Based Development; UNDP Regional Bureau for Europe and the Commonwealth of Indipendent States: Bratislava, Slovakia, 2006. 
39. Marczis, M. Tools and Case to National Programming on Area-Based Development for Inclusion; John Wiley \& Sons, Ltd.: Hoboken, NJ, USA, 2013; ISBN 978-1-4443-2944-5.

40. Vranken, J.; Decker, P.D.; Nieuwenhuyze, I.V. Social Inclusion, Urban Governance and Sustainability: Towards a Conceptual Framework for the UGIS Research Project; Garant: Antwerp, Belgium, 2002.

41. Atkinson, R. The Emerging "Urban Agenda" and the European Spatial Development Perspective: Towards an EU Urban Policy? Eur. Plan. Stud. 2001, 9, 385-406. [CrossRef]

42. Crowley, L.; Balaram, B.; Lee, N. People or Place? Urban Policy in the Age of Austerity; Work Foundation: London, UK, 2012.

43. Fenton, A.; Markkanen, S.; Tyler, P.; Clarke, A.; Whitehead, C.M.E. Why do Neighbourhoods Stay Poor? Deprivation, Place and People in Birmingham: A Report to the Barrow Cadbury Trust. Available online: http://www.cchpr.landecon.cam.ac.uk/ (accessed on 24 June 2020).

44. Lawless, P. Understanding the Scale and Nature of Outcome Change in Area-Regeneration Programmes: Evidence from the New Deal for Communities Programme in England. Environ. Plan. C Gov. Policy 2011, 29, 520-532. [CrossRef]

45. Rhodes, J.; Tyler, P.; Brennan, A. Assessing the Effect of Area Based Initiatives on Local Area Outcomes: Some Thoughts Based on the National Evaluation of the Single Regeneration Budget in England. Urban Stud. 2005, 42, 1919-1946. [CrossRef]

46. Smith, G.R. Area-Based Initiatives: The Rationale and Options for Area Targeting; London School of Economics and Political Science: London, UK, 1999.

47. Deas, I.; Robson, B.; Wong, C.; Bradford, M. Measuring Neighbourhood Deprivation: A Critique of the Index of Multiple Deprivation. Environ. Plan. C Gov. Policy 2003, 21, 883-903. [CrossRef]

48. Noble, M.; Smith, G.; Penhale, B.; Dibben, C.; Owen, T.; Lloyd, M. Measuring Multiple Deprivation at the Small Area Level. The Indices of Deprivation; Office of the Deputy Prime Minister: Mbabane, Swaziland, 2000.

49. Noble, M.; Wright, G.; Smith, G.; Dibben, C. Measuring Multiple Deprivation at the Small-Area Level. Environ. Plan. Econ. Space 2006, 38, 169-185. [CrossRef]

50. Ferris, J.M.; Hopkins, E. Place-Based Initiatives: Lessons from Five Decades of Experimentation and Experience. Found. Rev. 2015, 7, 97-109. [CrossRef]

51. Galster, G. On the Nature of Neighbourhood. Urban Stud. 2001, 38, 2111-2124. [CrossRef]

52. Taylor, M.; Buckley, E.; Hennessy, C. Historical Review of Place Based Approaches; Institute for Voluntary Action Research: London, UK, 2017.

53. Bramley, G. Scotland's Index of Multiple Deprivation: Assessing Its Statistical Validity, and Its Appropriateness as a Mechanism for Targeting Resources on Deprivation; Heriott Watt University: Edinburgh, UK, 2005.

54. Tunstall, R.; Lupton, R. Is Targeting Deprived Areas an Effective Means to Reach Poor People? An Assessment of One Rationale for Area-Based Funding Programmes; CASE Paper; Centre for Analysis of Social Exclusion, London School of Economics and Political Science: London, UK, 2003; Volume 70.

55. McKendrick, J.H.; Barclay, C.; Carr, C.; Clark, A.; Holles, J.; Perring, E.; Stien, L. Our Rural Numbers Are Not Enough: A Position Statement and Recommendations to Improve the Identification of Poverty, Income Inequality and Deprivation in Rural Scotland; Rural Poverty Indicators Action Learning Set: Glasgow, UK, 2011.

56. Clelland, D.; Hill, C. Deprivation, policy and rurality: The limitations and applications of area-based deprivation indices in Scotland. Local Econ. J. Local Econ. Policy Unit 2019, 34, 33-50. [CrossRef]

57. Midgley, J.; Hodge, I.; Monk, S. Patterns and Concentrations of Disadvantage in England: A Rural-Urban Perspective. Urban Stud. 2003, 40, 1427-1454. [CrossRef]

58. Chalmers, C. The 2001 Index of Multiple Deprivation (Unpublished Report to the Greater London Authority); The Queen's Walk: London, UK, 2000.

59. Marcuse, P. Enclaves yes, ghettos no: Segregation and the state. In Desegregating the City: Ghettos, Enclaves, and Inequality. Ghettos, Enclaves, and Inequality; State University of New York Press: Albany, NY, USA, 2005; pp. 15-30.

60. Taylor, M. Neighbourhood governance: Holy Grail or poisoned chalice? Local Econ. 2003, 18, 190-195. [CrossRef]

61. Andersen, H.S. Can Deprived Housing Areas Be Revitalised? Efforts against Segregation and Neighbourhood Decay in Denmark and Europe. Urban Stud. 2002, 39, 767-790. [CrossRef] 
62. OPDM. Turning Areas Around: The Impact of the SRB on Final Outcomes. Available online: https://www.landecon.cam.ac.uk/pdf-files/urban-and-regional-analysis/part3-final-eval-feb-07.pdf (accessed on 24 June 2020).

63. Marcuse, P. Spatial Justice: Derivative but Causal of Social Injustice. In Justices et Injustices Spatiales; Presses Universit: Paris, France, 2010; pp. 75-94.

64. Pugalis, L. Hitting the target but missing the point: The case of area-based regeneration. Community Dev. 2013, 44, 617-634. [CrossRef]

65. Rae, A. Learning from the Past? A Review of Approaches to Spatial Targeting in Urban Policy. Plan. Theory Pract. 2011, 12, 331-348. [CrossRef]

66. Chatterton, P.; Bradley, D. Bringing Britain Together? The limitations of area-based regeneration policies in addressing deprivation. Local Econ. J. Local Econ. Policy Unit 2000, 15, 98-111. [CrossRef]

67. Tosics, I. Dilemmas of Integrated Area-Based Urban Renewal Programmes. Urbact Trib. 2009, 21-37.

68. Suttles, G.D. The Social Construction of Communities; University of Chicago Press: Chicago, IL, USA, 1972.

69. Prime Minister's Strategy Unit. Improving the Prospects of People Living in Areas of Multiple Deprivation; Cabinet Office: London, UK, 2005.

70. Atkinson, R.; Kintrea, K. Disentangling Area Effects: Evidence from Deprived and Non-deprived Neighbourhoods. Urban Stud. 2001, 38, 2277-2298. [CrossRef]

71. Burgess, P. Devolved Approaches to Local Governance: Policy and Practice in Neighbourhood Management; Project Report; Joseph Rowntree Foundation: York, UK, 2001; ISBN 978-1-84263-012-9.

72. Carley, M.; Kirk, K. Sustainable by 2020? A Strategic Approach to Urban Regeneration for Britain's Cities; Policy Press: Bristol, UK, 1998; ISBN 978-1-86134-104-4.

73. Baumont, C. Spatial effects of urban public policies on housing values. Pap. Reg. Sci. 2009, 88, 301-326. [CrossRef]

74. Melo, B.; Cruz, C.O. Effect of Private Externalities in Urban Housing Renewal Investment: Empirical Assessment Using a Game-Theory Approach. J. Urban Plan. Dev. 2017, 143, 04017015. [CrossRef]

75. Manley, D.; Ham, M.; van Bailey, N.; Simpson, L.; Maclennan, D. (Eds.) Neighbourhood Effects or Neighbourhood Based Problems? A Policy Context; Springer Netherlands: Dordrecht, The Netherlands, 2013; ISBN 978-94-007-6694-5.

76. Miceli, T.J.; Sazama, G.W.; Sirmans, C.F. Managing Externalities in Multi-Unit Housing: Limited Equity Cooperatives as Alternatives to Public Housing. J. Policy Model. 1998, 20, 649-668. [CrossRef]

77. Mattarocci, G. Interventi di rigenerazione urbana e valore degli immobili il caso di Milano. In Rigenerazione Urbana e Mercato Immobiliare; Roma Tre-Press: Roma, Italy, 2018; pp. 32-51.

78. Tang, B.; Wong, K.T. Assessing externality: Successive event studies on market impacts of new housing development on an old residential neighbourhood. Environ. Plan. B Urban Anal. City Sci. 2020, 47, 156-173. [CrossRef]

79. Lee, C.; Culhane, D.P.; Wachter, S.M. The differential impacts of federally assisted housing programs on nearby property values: A philadelphia case study. Hous. Policy Debate 1999, 10, 75-93. [CrossRef]

80. Newman, S.J.; Schnare, A.B. “ ... And a suitable living environment": The failure of housing programs to deliver on neighborhood quality. Hous. Policy Debate 1997, 8, 703-741. [CrossRef]

81. Freeman, L.; Botein, H. Subsidized Housing and Neighborhood Impacts: A Theoretical Discussion and Review of the Evidence. J. Plan. Lit. 2002, 16, 359-378. [CrossRef]

82. Rossi-Hansberg, E.; Sarte, P.; Owens, R. Housing Externalities. J. Polit. Econ. 2010, 118, 485-535. [CrossRef]

83. De Sousa, C.A.; Wu, C.; Westphal, L.M. Assessing the Effect of Publicly Assisted Brownfield Redevelopment on Surrounding Property Values. Econ. Dev. Q. 2009, 23, 95-110. [CrossRef]

84. Ding, C.; Simons, R.; Baku, E. The Effect of Residential Investment on Nearby Property Values: Evidence from Cleveland, Ohio. J. Real Estate Res. 2000, 19, 23-48. [CrossRef]

85. Simons, R.A.; Quercia, R.G.; Maric, I. The Value Impact of New Residential Construction and Neighborhood Disinvestment on Residential Sales Price. J. Real Estate Res. 1998, 15, 147-162.

86. Collins, W.J.; Shester, K.L. Slum Clearance and Urban Renewal in the United States. Am. Econ. J. Appl. Econ. 2013, 5, 239-273. [CrossRef]

87. Newell, T.A. Development and Neighborhood Revitalization: The Effects of Residential Investment on Property Values in Durham, NC. J. Bus. 2009, 2, 97-120. 
88. Gibbons, S. Paying for Good Neighbours: Estimating the Value of an Implied Educated Community. Urban Stud. 2003, 40, 809-833. [CrossRef]

89. Atkinson, R. Does Gentrification Help or Harm Urban Neighbourhoods? An Assessment of the Evidence-Base in the Context of the New Urban Agenda. Cent. Neighb. Res. Pap. 2002, 5, 1-27.

90. Malpezzi, S. Housing Prices, Externalities, and Regulation in U.S. Metropolitan Areas. J. Hous. Res. 1996, 7, 209-241.

91. Vigdor, J.L. Is urban decay bad? Is urban revitalization bad too? J. Urban Econ. 2010, 68, 277-289. [CrossRef]

92. Della Spina, L.; Calabrò, F.; Rugolo, A. Social Housing: An Appraisal Model of the Economic Benefits in Urban Regeneration Programs. Sustainability 2020, 12, 609. [CrossRef]

93. Chau, K.W.; Wong, S.K. Externalities of Urban Renewal: A Real Option Perspective. J. Real Estate Financ. Econ. 2014, 48, 546-560. [CrossRef]

94. Galster, G.C. What is neighbourhood? An externality-space approach. Int. J. Urban Reg. Res. 1986, 10, $243-263$. [CrossRef]

95. Otto, D.A.; Whinston, A.B. The Economics of Urban Renewal. Law Contemp. Probl. 1961, 26, 105-117.

96. Galster, G. Neighbourhood Social Mix as a Goal of Housing Policy: A Theoretical Analysis. Eur. J. Hous. Policy 2007, 7, 19-43. [CrossRef]

97. Saiu, V. The Three Pitfalls of Sustainable City: A Conceptual Framework for Evaluating the Theory-Practice Gap. Sustainability 2017, 9, 2311. [CrossRef]

Publisher's Note: MDPI stays neutral with regard to jurisdictional claims in published maps and institutional affiliations. 